\title{
OS5-1＼cjkstart燃料電池車用ジメチルエーテル低温水蒸気改質器の開発
}

\author{
松田直彦 ${ }^{* 1}$ ，八木克記 ${ }^{* 2}$ \\ 野島繁 *2, 鈴木信市*3
}

\section{Development of DME Autothermal Reforming System for Fuel cell Vehicles}

\author{
Naohiko MATSUDA ${ }^{*_{1}}$, Katsuki YAGI ${ }^{*_{2}}$, \\ Shigeru NOJIMA ${ }^{*_{2}}$ and Shinichi SUZUKI ${ }^{{ }_{3}}$ \\ *1,2 Mitsubishi Heavy Industries, LTD. Technical Headquartess Hiroshima Reseanch\&Development Center6-22, 4-Chome, \\ Kanonshinmachi, Nishiku, Hinhoshima7338553 Japan \\ *3 Japan OilGas andMetal National Corporation, 1310 Omiyacho, Saiwaiku, Kawasakinity, Kanagawa, 212-8504 Japan
}

Dimethyl ether (DME) is stutadle fuel far on boand refaning. We have developed 30kW autothermal antoond DME neformer. This refomer is padked in 50 littens. The load dhange response is under 10 seconds and $O O$ concentration in reformed gas iskept under $10 \mathrm{ppm}$ In addition to these experiments, we have developed a DME reforming FC simulator. By inputtingexperimental dataof neformer, we have got required battery sise, fuel consumption. Through these experiments and simulation, we have evaluated the convenience of anboand DME refoming system for furd cell vehides :

KeyWands: $\quad$ DME,Fudoll, Reformer

\section{1. 粕論}

燃料電池は、将来の自動車用動力として有望視さ れ数々の開発が行われている。しかし、燃料電池の燃 料である水素を車上で貯蔵する方法力課題である。現 在 自動車メ一カーでは玨縮水素方式を中心的に採用 しているが、航続距離を伸ばすための車搭タンク高圧 化、水素スタンド設置なと課題が多い。

一方、オンボード改質方法は、改質器の応答性の 課題はあるものの、液体燃料使用により上記問題か解 決出来る。図1にオンボード改質の基本構成を示す。 燃料を改質器で水素含有ガスに変換し、燃料電池へ供 給、発電する。燃料電池加らの残水素は、改質器の熱 源として再利用する。また、燃料電池とモ一タ一の間 には 2 次電池があり、改質器の応答遅れを補完する役 目を担う。

\section{*原稿受付 2006 年 5 月 19 日.}

${ }^{* 1}$ 正員, 三菱重工業株) 広島研究所（广733-8553 広島市西区観音 新町 46-22).

2 三菱重工業侏）広島研究所（广733-8553 広島市西区観音新町 46 22)

独石油天然ガス・金属鈸物資源機構（テ212-8554 神奈川県川崎 市幸区大宮町 1310番ミューザ川崎セントラルタワー5階)

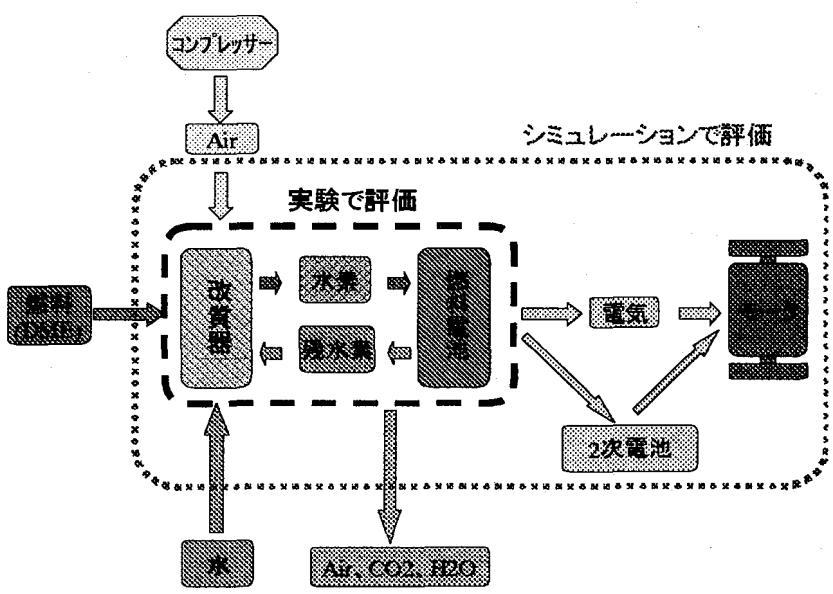

図 1 オンボード改質の基本構成

現在、石油代替エネルギーとして生産がおこなわ れつつあるジメチルエーテルは、オンボード改質の燃 料として以下の点に優れている。

(1) 硫黄分を含まないために脱硫器が不要。

(2) 低温度 (約 $400^{\circ} \mathrm{C}$ ) て改質が可能。

(3) 常温、低圧(約 $0.4 \mathrm{Mpa}$ )で液体貯蔵が出来る。

(4) LPGスタンドインフラ流用可能

本報告では、このジメチルエーテルを燃料とした 車載用改質器の開発状況を報告する。

筆者らが採用した改質の方法は内部加熱型で、改 質反応に必要な熱を、原料に混入した酸素とジメチル エーテルとの反応熱で供給する方法であり、伝熱面積 
か不要で改質器をコンパクトにでき、応答性も速い利 点がある。改質器の基本構成を図 2 に示す。まず、蒸 発器で水蒸気を発生、ジメチルエーテルと内部加熱用 空気を混入させて改質触媒へ流入して主に水素を生成。 次に、 $\infty O$ シフト触媒， 0 除去触媒を配置し、ガス 中の $\bigcirc$ 濃度を随時低减させて、最終的に $10 \mathrm{ppm}$ 以 下にして燃料電池一供給する。

各触某での反応を式 1 ～ 4 に示す。

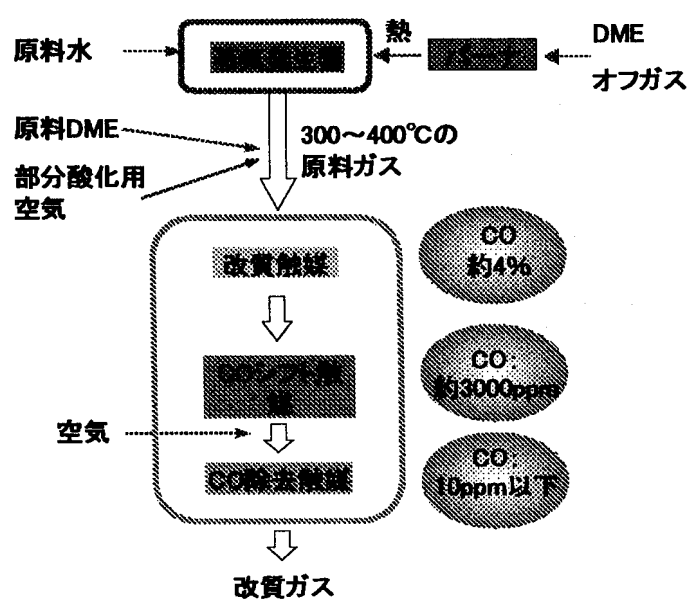

$\mathrm{H}_{2} 47.6 \%, \mathrm{CO}_{2} 18.7 \%, \mathrm{H}_{2} \mathrm{O} 17.8 \%, \mathrm{~N}_{2} 15.9 \%$ CO 10ppm以下

図 2 改質器の基本構成

(改質触某内での反応)

$\mathrm{CH}_{3} \mathrm{OCH}_{3}+1 / 2 \mathrm{O}_{2} \rightarrow 2 \mathrm{CO}+3 \mathrm{H}_{2}$ (部分酸化) 式 1

$\mathrm{CH}_{3} \mathrm{OCH}_{3}+3 \mathrm{H}_{2} \mathrm{O} \rightarrow 2 \mathrm{CO}_{2}+6 \mathrm{H}_{2}$ (水蒸気改質) 式 2

(CO シフト触某での反忘)

$\mathrm{CO}+\mathrm{H}_{2} \mathrm{O} \rightarrow \mathrm{CO}_{2}+\mathrm{H}_{2}$

(CO除去触媒での反応)

$\mathrm{CO}+1 / 2 \mathrm{O}_{2} \rightarrow \mathrm{CO}_{2}$ 式3

式4

使用する改質触媒は銅、アルミナベースで、耐久

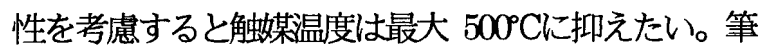
者らはこの問題に対して図 3 に示す 2 段空気供給方 法を開発して、改質触媒温度を低减することに成功し た。 1 段で内部嗔用空気を供給した時は、すべての 空気を一度に流入するために、触媒入口温度が上昇し て約 $700{ }^{\circ}$ まで到達する。

一方、2段空気供給方法では、改質触媒を 2 段に分 割して、それぞれの入口で空気を供給するために、温 度上昇が分割されて、触媒温度を $500^{\circ} \mathrm{C}$ 以下に抑制す ることが出来た。

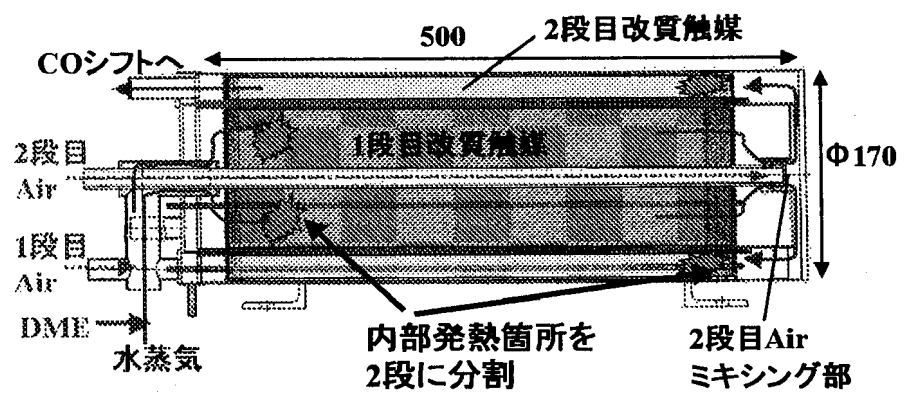

図3 2段空気供給方法の構造

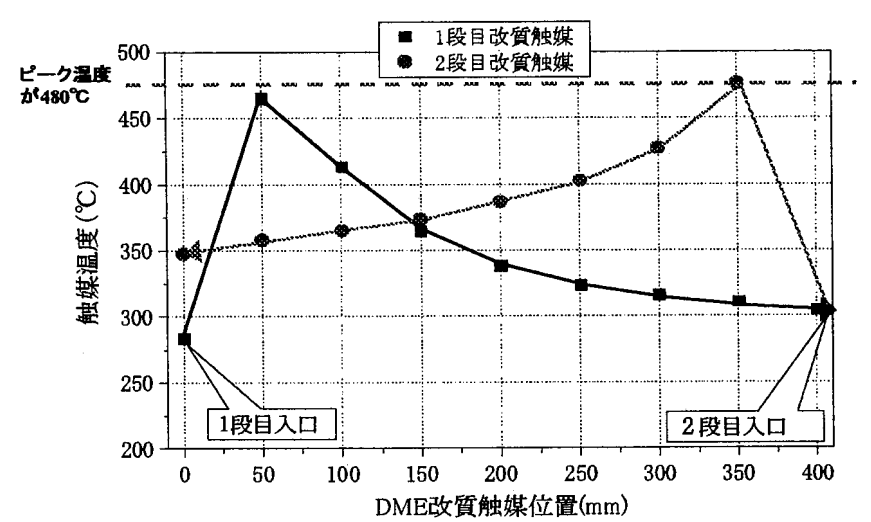

図4２段空気供給法による触某温度分布

\section{2 改覧器の粠成}

開発した改質器の基本構成と概観写真を図 5 に示 す。コンパクト性を向上させるために、蒸発器とバー ナ一を改質触媒部に内蔵し 00 シフト触某と 00 除 去触媒は一体化してある。基本仕椂は表 1 に示すよう に、サイズ $50 \mathrm{~L}$ 以下で $30 \mathrm{kWe}$ 発電相当の水素 $425 \mathrm{~N} L / \mathrm{min}$ を発生させる。

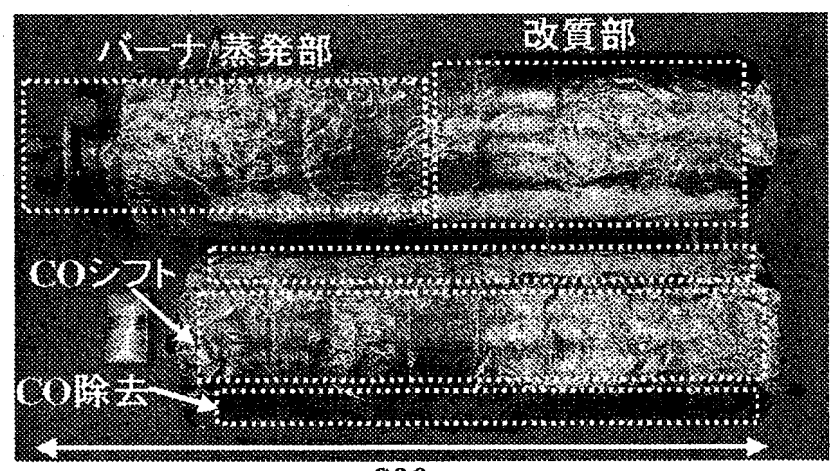

800

図 5 改質器の基本構成 
表 1 改質器の仕様

\begin{tabular}{|l|l|}
\hline 項目 & \multicolumn{1}{|c|}{ 仕様 } \\
\hline サイズ & \multicolumn{1}{|c|}{$42 \mathrm{~L}$} \\
\hline 重量 & \multicolumn{1}{|c|}{$58 \mathrm{~kg}$} \\
\hline 発生水素量 & \multicolumn{1}{|c|}{$425 \mathrm{NL} / \mathrm{min}$} \\
\hline 負荷応答性 & 負荷範囲 $36 \sim 100 \%$ \\
& $36 \rightarrow 100 \%: 10$ 秒 \\
& $100 \rightarrow 36 \%: 5$ 秒 \\
\hline 起動時間 & 常温から 10分 \\
& 3分停止後りスタート1分 \\
\hline
\end{tabular}

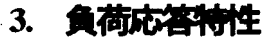

車載改質器には、車での運用を考えると可能な限り 速い応答か㴗求さ、同時に燃料電池被毒を起こす $\infty$ の濃度を 10ppm 以下にする必要がある。もし 00 濃 度が増大すれば、燃料電池の電圧か著しく低下して、 発電電力の低下、燃料電池の寿命低下を招く。開発し た改質器の応答特性を、前述記載の表 1 に併記する。

図 6 に本改質器を連続的に 10 回負荷変動させたと きの改質器出口 00 濃度変動を示す。

若干の $\infty$ 濃度変化はみられるものの、常に CO10ppm 以下に抑えることが出来ている。

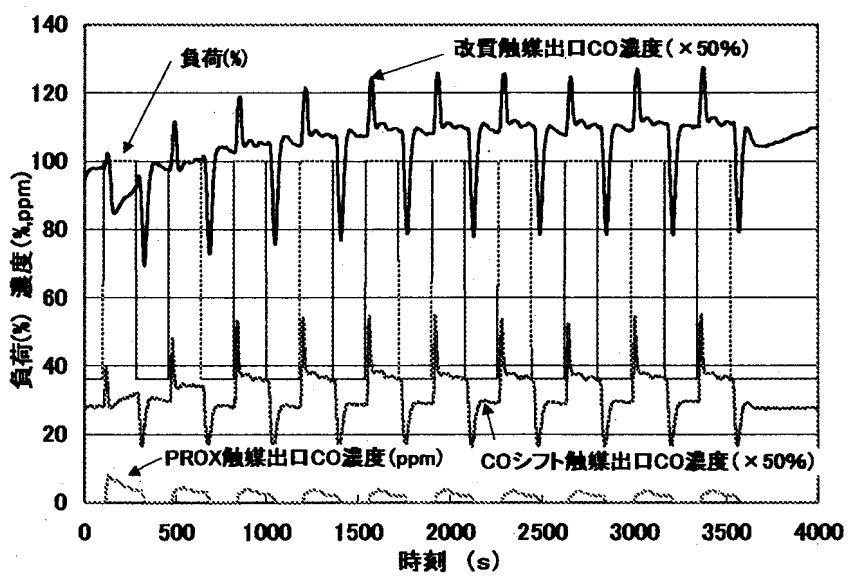

図6 連続負荷変動時の 00 濃度変化

負荷 UP,DOWNでのガス流量の変動を図 7、8に示 す。負荷 UP時には水蒸気流量 UPに多少の遅れが見 られるが、約 10 秒以内には負荷 $100 \%$ 相当の水蒸気 流量に到達し、それにあわせて原料 DME を増大する ことで改質ガス流量を $100 \%$ まで増大することが出来 る。
一方、負荷 Down 時は、蒸発器からの水蒸気量低下 速度がさらに速く、約 5 秒で改質ガスを低負荷まで低 減することが出来る。

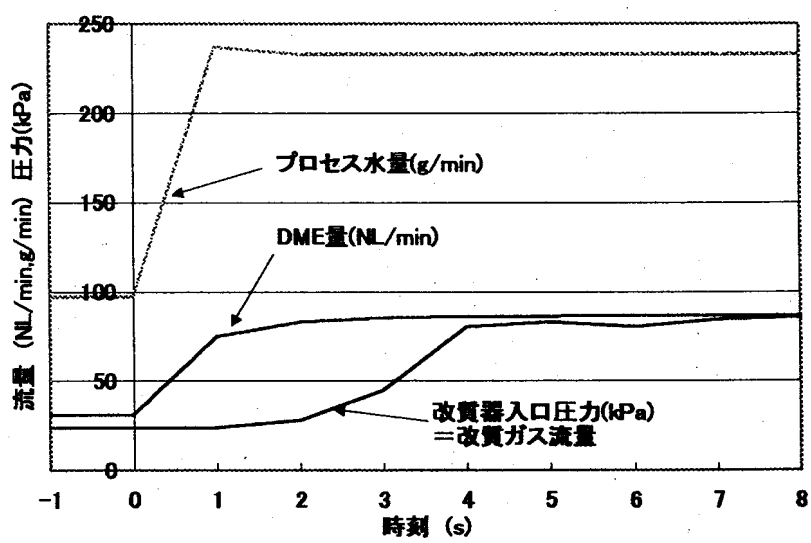

図 7 負荷UP時の流量変化

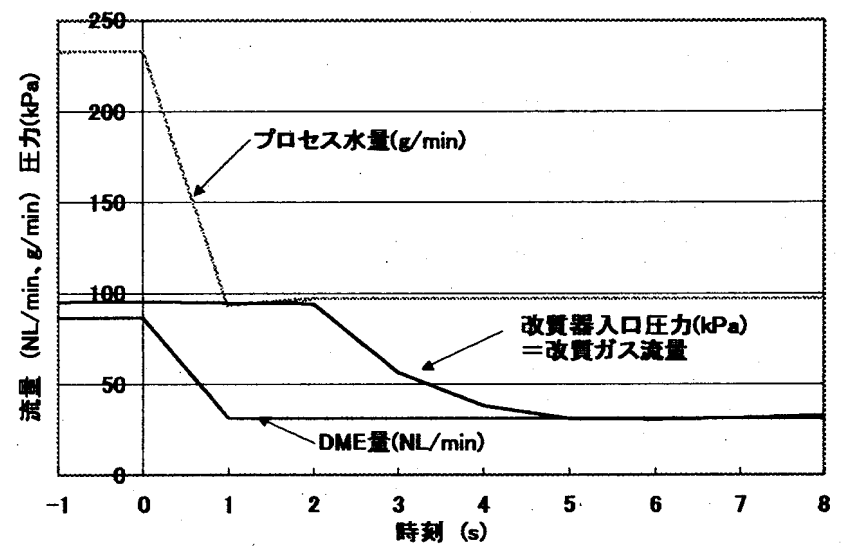

図 8 負荷Down 時の流量変化

\section{4. 改畏器の起方方法}

車載改質器には起動が遅い問題がある。改質器よ触 媒を収納した容器であり、この触媒を所定の温度にし なければ CO10ppm 以下の水素ガス生成は不可能であ る。内部加勲型改質器は、触某内の発熱で熱供給する ために熱伝達面を持ち合わせていない。これは改質器 のコンパクト化に優位であるが、逆に昇温手段がない ことを示す。

この課題に対して筆者らは、酸素レスガスを触某に 直接流入することで解决した。図9にそのシステム概 要を示す。本システムでは空気此 $0.7 \sim 0.8$ の条件でバ 一ナ一を燃焼させ、表 $2 に$ 示す酸素濃度の低いガスを 発生させ、触某に流入する。

図 10 にこの方法で害施した各触媒の昇温履歷を示 す。試験では約 10 分で各触媒が反応に適切な温度に 到達することを確認した。 


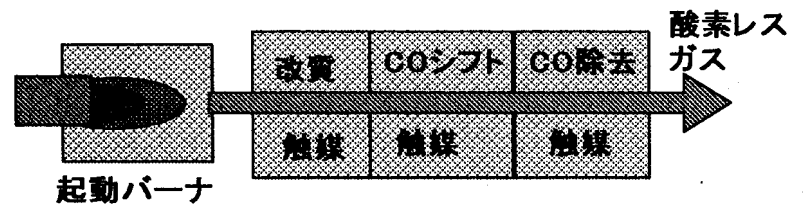

図 9 酸素レスバーナーの昇温システム

表2 酸素レスバーナ一の排ガス組成

\begin{tabular}{|c|c|}
\hline ガス成分 & 濃度(\% Dry) \\
\hline $\mathrm{H}_{2}$ & 8.5 \\
\hline $\mathrm{CH}_{4}$ & 0.1 \\
\hline $\mathrm{O}_{2}$ & 0.2 \\
\hline $\mathrm{CO}_{2}$ & 10.6 \\
\hline $\mathrm{CO}_{2}$ & 8.0 \\
\hline $\mathrm{DME}$ & 0.0 \\
\hline $\mathrm{N}_{2}$ & 70.1 \\
\hline
\end{tabular}

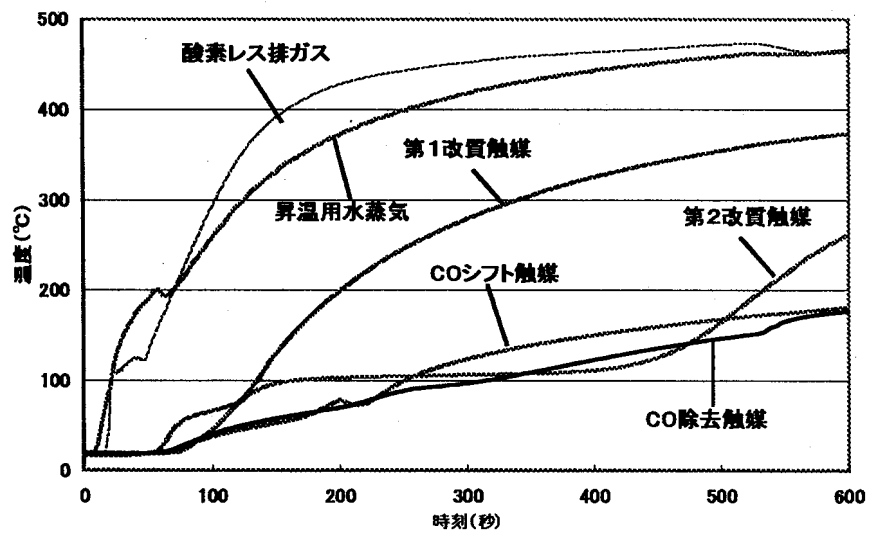

図 10 起動バーナーによる改質器内触媒景温結果

\section{5. 車往シミレーション}

筆者らは、改質器本体の開発のみでなく改質器を燃 料電池車でどのように運用するかを評価するために、 車載シミュレーションも実施している。図 11 にその シミュレーションモデル概略を示す。燃料電池からの 電力過不足を補完する形で 2 次電池を設置してある。

シミュレーションでは、主に2つの項目を評価して いる。

(1) 改質器起動 燃料電池発電までの間に車を動 かすための 2 次電池容量
（2）10-15 モード、LA-4 モードで負荷運転した場合 の 2 次電池、改質器二燃料電池発電のそれそれ の負担状態

図 12 には、LA-4モ一ド運軴特の車速、モ一夕一要求

電力、燃料電池発電電力の計算例を示す。

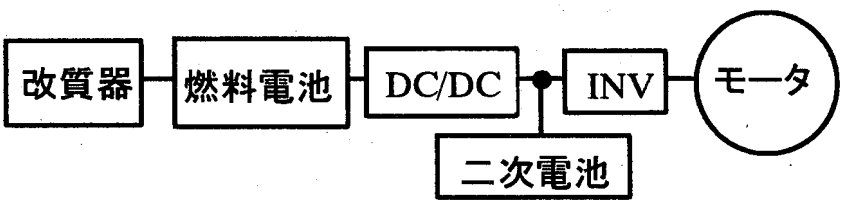

図 11 車載シミュレーションモデル

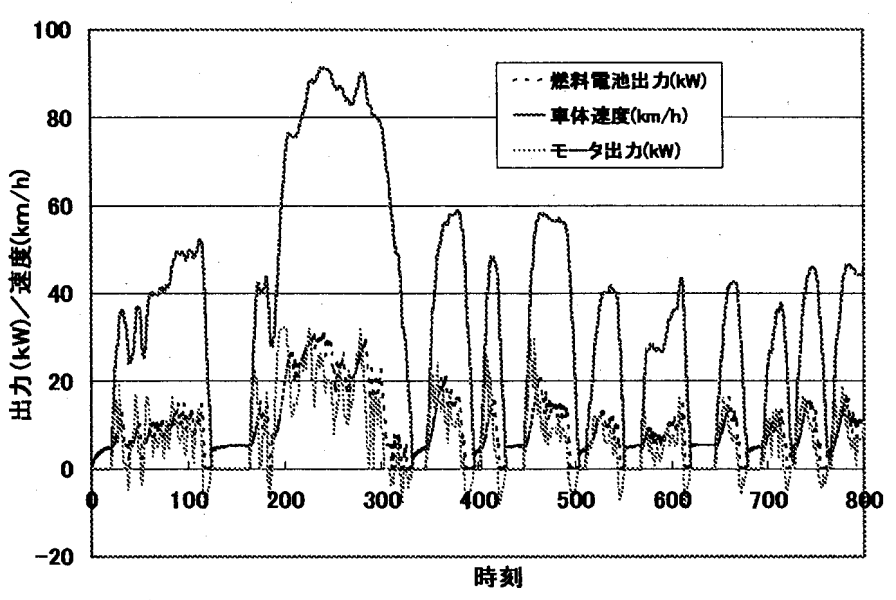

図 12 LA-4モードでの負荷変動計算例

\section{6. 結雫}

現在までに、前述の応答性をもつ改質器を開発した。 今後は、以下の項目を更に進める。

(1) 起動時間の短縮による 2 次電池容量の低减

(2) 改質器本体の更なるコンパクト化

(3) 車載シミュレーションによる運転条件最適化

口最後に、この研究は、独立行政法人 石油天然力゙ ス・金属鉱物資源機構の委琣研究で平成 15 年から平 成 19 年の 4 力年計画で実施しており、大阪ガス株式 会社、日揮株式会社、三菱ガス化学株式会社、ルネッ サンス・エナジー・リサーチ株式会社との共同研究に より実施している。 